\title{
Genetic structure of the snakehead murrel, Channa striata (channidae) based on the cytochrome c oxidase subunit I gene: Influence of historical and geomorphological factors
}

\author{
Jamsari Amirul Firdaus Jamaluddin ${ }^{1}$, Tan Min Pau ${ }^{1}$ and Mohd Nor Siti-Azizah ${ }^{1,2^{*}}$ \\ ${ }^{1}$ School of Biological Sciences, Universiti Sains Malaysia, Penang, Malaysia. \\ ${ }^{2}$ Centre for Marine and Coastal Studies, Universiti Sains Malaysia, Penang, Malaysia.
}

\begin{abstract}
Nucleotide sequences of a partial cytochrome c oxidase subunit I gene were used to assess the manner in which historical processes and geomorphological effects may have influenced genetic structuring and phylogeographic patterns in Channa striata. Assaying was based on individuals from twelve populations in four river systems, which were separated into two regions, the eastern and western, of the biodiversely rich state of Perak in central Peninsular Malaysia. In 238 specimens, a total of 368-bp sequences with ten polymorphic sites and eleven unique haplotypes were detected. Data on all the twelve populations revealed incomplete divergence due to past historical coalescence and the short period of separation. Nevertheless, SAMOVA and $\mathrm{F}_{\mathrm{ST}}$ revealed geographical structuring existed to a certain extent in both regions. For the eastern region, the data also showed that the upstream populations were genetically significantly different compared to the mid- and downstream ones. It is inferred that physical barriers and historical processes played a dominant role in structuring the genetic dispersal of the species. A further inference is that the Grik, Tanjung Rambutan and Sungkai are potential candidates for conservation and aquaculture programmes since they contained most of the total diversity in this area.
\end{abstract}

Key words: Channa striata, mtDNA COI, Phylogeography, Population structure.

Received: April 12, 2010; Accepted: October 13, 2010.

\section{Introduction}

Channa striata, locally known as haruan or snakehead murrel, an eminent tropical freshwater fish widely used for medicinal and pharmaceutical purposes (Mat Jais et al., 1994; Michelle et al., 2004), is also an important food source in the Asia-Pacific region (Froese and Pauly, 2008; Hossain et al., 2008). This carnivorous airbreather species is encountered in rivers, swamps, ponds, canals, drains, reservoirs, rice fields, small streams, mining pools, roadside ditches and lakes, across southern Asia, southern China, Indochina and the Sunda Islands (Mohsin and Ambak, 1983; Lee and Ng, 1994; Hossain et al., 2008). In Malaysia, and due to its abundance in nature, it is normally marketed alive, fresh from the catch. Aquaculture itself is only significant in certain neighbouring countries, such as Thailand, Pakistan, Taiwan, the Philippines, Vietnam, Cambodia and India (Wee, 1982; Hossain et al., 2008). The aquacultural potential of the species in Malaysia, has, as yet, not been fully exploited despite its many advantageous characteristics, notably high market price, air

Send correspondence to Siti Azizah Mohd Nor. School of Biological Sciences, Universiti Sains Malaysia, 11800 Minden, Penang, Malaysia. E-mail: sazizah@usm.my. breathing ability, hardiness and high tolerance to adverse environmental conditions (Samantaray and Mohanty, 1997; Ali, 1999; Froese and Pauly, 2008). As is frequently observed in many important food-fish, overharvesting and other anthropogenic factors have resulted in severe damage to its natural habitat, with a subsequent decline in the indigenous stock of the species (Nagarajan et al., 2006; Hossain et al., 2008). Furthermore, unsystematic hatchery programmes can also lead to inbreeding depression, with a possible reduction in fecundity, adaptation ability and survival rate (Beaumont and Hoare, 2003; Sun et al., 2004). Hence, in order to effectively conserve and manage the fish, vital information on relevant population genetics is required, specifically through assessment of its genetic diversity and structuring for potential brood-stock identification. Previous studies have focused on reproductive biology (Ali, 1999), medical and pharmaceutical properties (Baie and Sheikh, 2000; Michelle et al., 2004), biochemical composition (Zuraini et al., 2006; Zakaria et al., 2007), ecology (Lee and Ng, 1994; Amilhat and Lorenzen, 2005), breeding (Haniffa et al., 2000), diet (Roshada, 1994; Arul, 2008) and morphological characters (Chandra and Banerjee, 2004), with only limited available information on population genetics of the species, especially in Malaysia. Ambak et al. 
(2006) and Mat Jais et al. (2009), when examining the genetic structure of snakeheads from Peninsular Malaysia based on RAPD and RFLP data, reported a positive corelation between hydro-geographic factors (mainly due to the Titiwangsa Mountain Range) and population genetic differentiation, respectively. Hara et al. (1998) also reported similar geographic structuring of $C$. striata in Thailand, based on allozymic data.

A typical example of the common aspect of natural landscapes of Peninsular Malaysia (Mohsin and Ambak, 1983), the state of Perak, situated in the central-western region, is overspread with pronounced geographical features, complex natural ecological heterogeneity and dense short river tributaries connecting and running into the Strait of Malacca, thereby sustaining rich biodiversity. Little is known regarding the influence of Pleistocene climate fluctuations and geomorphological processes involving drainage re-arrangements, ecological changes and natural or anthropogenic physical barriers, that have lead to the current biotic composition of Malaysia in general and Perak State specifically. The Chenderoh dam, and the Bintang and Keledang mountain ranges, as well as the Kerian and Perak rivers and their tributaries, are among the significant geographical features dominating the local landscape. These are probably the factors mainly involved in shaping the genetic pattern of regional biotic systems. Moreover, deglaciation during the late Pleistocene is believed to have periodically separated the two main rivers in the region, the Kerian and Perak, as well as their tributaries. According to the prevailing hypothesis, during the Pleistocene these two rivers coalesced, thus constituting a single course that ran north to the Andaman Sea (Voris, 2000). Therefore, Pleistocene climate fluctuations possibly played a significant role in genetic distribution, through changes in the physical land surface, habitats and the natural range of many regional species.

In this study, the mitochondrial cytochrome c oxidase subunit I (COI) gene was partially sequenced to examine the genetic diversity and structure of $C$. striata populations within Perak state in the central Peninsular Malaysia and particularly to infer the mechanisms or forces most likely to have been involved in shaping these populations, thus providing critical genetic information for brood-stock management and species conservation.

\section{Material and Methods}

\section{Sample acquisition}

A total of 238 individuals of $C$. striata, representing twelve populations throughout Perak state, were sampled from the wild during the period 2007 to 2009. These populations were classified into four categories, according to their placing along the respective river system. The Grik, Tanjung Rambutan and Sungkai populations, through being the closest to their origins, were then considered as up- stream populations, whereas, the Tapah, Kubu Gajah, Lenggong and Ulu Kinta were clustered as upper-mid stream, the Kuala Kangsar and Gopeng as mid-stream, and finally, the Parit Buntar, Kampung Gajah and Teluk Intan as downstream populations. These populations were further divided into two major regions, the eastern and western, effectively separated by the Bintang mountain range. Only one single river system, the Kerian river, was investigated in the western region. Since the eastern covered a larger area, with several distinct tributaries, this was further divided into three riverine systems, namely the Perak, Kinta and Batang Padang - Sungkai. Two further significant geographical landmarks in this area are (1) the Keledang mountain range, which partially separates the Perak and Kinta rivers along the upper-mid stream, and (2) the Chenderoh dam, built across Perak river. Details of sampling locations, and region and sample sizes, are shown in Table 1 and Figure 1.

Tissues collected were dissected and preserved in TNES-urea $(100 \mathrm{mM}$ Tris- $\mathrm{HCl} \mathrm{pH} 7.5,125 \mathrm{mM} \mathrm{NaCl}$, $10 \mathrm{mM}$ EDTA pH 7.5, 1\% SDS, $3 \mathrm{M}$ urea), modified according to Valles-Jimenez et al. (2004), and 95\% ethanol (for long term preservation), prior to DNA extraction.

\section{DNA analysis}

An AquaGenomic DNA isolation Kit (BioSyntech, Salt Lake City, Utah, USA) was used for total DNA extraction from fins and muscles, according to manufacturer's in-

Table 1 - Sample localities and size (n) of Channa striata analysed in the present study.

\begin{tabular}{lcc}
\hline Sample & Location & Sample size (n) \\
\hline Western region & & \\
Kerian river system (A) & & \\
Kubu Gajah & $\mathrm{a} 1$ & 20 \\
Parit Buntar & $\mathrm{a} 2$ & 31 \\
Eastern region & & \\
Sungai Perak river system (B) & & \\
Grik & $\mathrm{b} 1$ & 12 \\
Lenggong & $\mathrm{b} 2$ & 13 \\
Kuala Kangsar & $\mathrm{b} 3$ & 15 \\
Kampung Gajah & $\mathrm{b} 4$ & 12 \\
Kinta river system (C) & & \\
Tanjung Rambutan & $\mathrm{c} 1$ & 30 \\
Ulu Kinta & $\mathrm{c} 2$ & 16 \\
Gopeng & $\mathrm{c} 3$ & 26 \\
Batang Padang - Sungkai river & & \\
system (D) & & 10 \\
Sungkai & $\mathrm{d} 1 \mathrm{a}$ & 20 \\
Tapah & $\mathrm{d} 1 \mathrm{~b}$ & 33 \\
Teluk Intan & $\mathrm{d} 2$ & 238 \\
Total & & \\
\hline
\end{tabular}




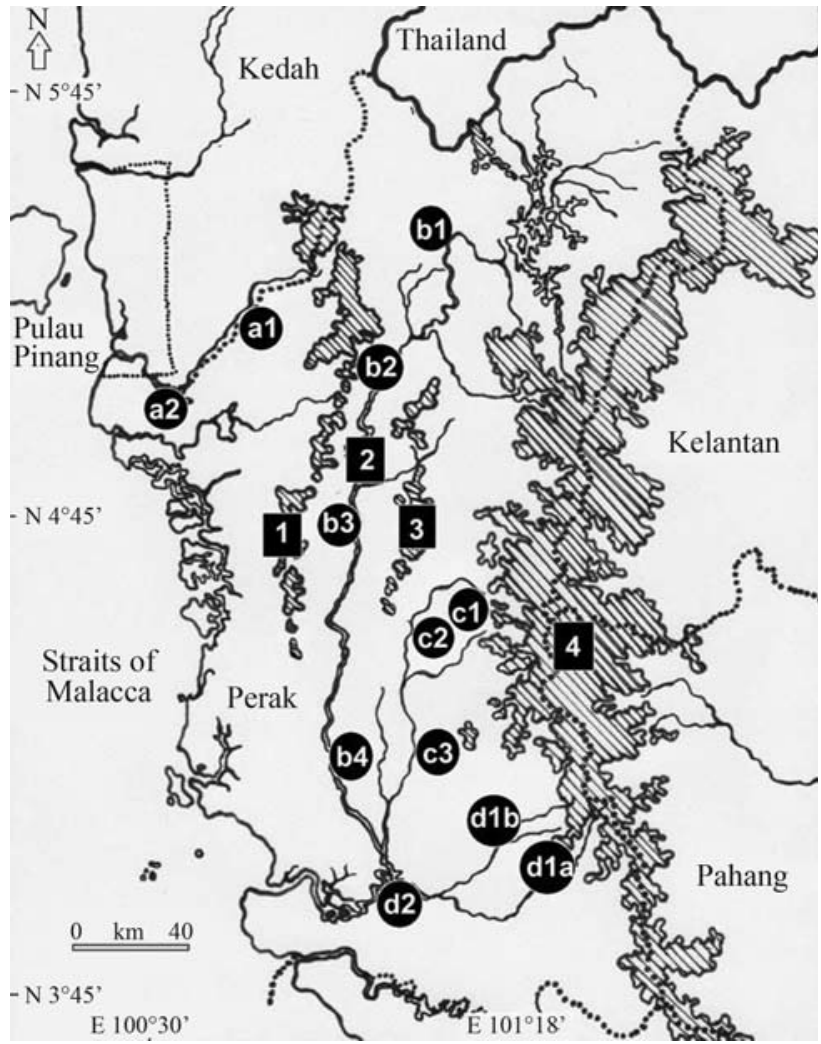

Figure 1 - Sampling locations of the twelve Channa striata populations analysed in the present study. Shaded areas represent mountain ranges and closed circles (alphabet) sampling sites, whereas the closed squares (number) are significant geographical landmarks, present in the region. (1) Bintang mountain range, (2) Chenderoh dam, (3) Keledang mountain range and (4) Titiwangsa mountain range.

structions. DNA integrity and quantities were assessed on $0.8 \%(\mathrm{w} / \mathrm{v})$ agarose gel, with a spectrophotometer (U-1900 UV/VIS spectrophotometer 200V - Hitachi, Tokyo, Japan). The DNA was then stored at $-20^{\circ} \mathrm{C}$ until use. A segment of the COI mtDNA gene was PCR-amplified using the primers L6154 (5'-AYC ARC AYY TRT TYT GRT TCT-3') and H6556 (5'-TGR AAR TGI GCI ACW ACR TA-3') (Teletchea et al., 2006). Amplification was with an MJ PTC-200 thermal cycler (MJ Research, Waltham, MA, USA) at a total volume of $25 \mu \mathrm{L}$ containing $1 \mathrm{X}$ PCR buffer, $4.2 \mathrm{mM} \mathrm{MgCl}_{2}, 0.2 \mathrm{mM}$ dNTPs, $0.6 \mu \mathrm{M}$ of each primer, $0.08 \mathrm{U}$ of Taq polymerase and 50 to $100 \mathrm{ng}$ of template DNA. The reaction programme was carried out initially at $95^{\circ} \mathrm{C}$ for $5 \mathrm{~min}$ followed by 30 cycles with the following profile: $94{ }^{\circ} \mathrm{C}$ for $60 \mathrm{~s}, 50{ }^{\circ} \mathrm{C}$ for $60 \mathrm{~s}, 70^{\circ} \mathrm{C}$ for $60 \mathrm{~s}$ and finally 5 min of final extension at $72{ }^{\circ} \mathrm{C}$. DNA amplification products were separated in $1.5 \%(\mathrm{w} / \mathrm{v})$ agarose gels at $100 \mathrm{~V}$ with $0.5 \mathrm{X}$ Tris-borate-EDTA (TBE) buffer, stained with ethidium bromide and visualized under UV illumination. PCR products were purified using a QIAquick PCR purification kit (Qiagen, Valencia, CA, USA), and sequenced using Big Dye Terminator v3.1 and an ABI3730XL
Genetic Analyzer (Applied Biosystems, Foster City, CA, USA).

\section{Data analysis}

Initial editing of ambiguous bases was undertaken with MEGA 4.0 software (Tamura et al., 2007). The edited sequences were then aligned by using Clustal W 1.6 implemented in the same software. The alignments thus obtained were further visually cross-checked. Amino acid sequence translation (vertebrate mitochondrial code) was applied to evaluate the accuracy of COI sequences, and then translated back for subsequent analysis. Collapse 1.2 (Posada, 2006) was used to determine identical haplotypes in the aligned matrix. All haplotypes were deposited in GenBank (accession numbers GQ244413 to GQ244422 and GQ334376). Molecular diversity indices [number of haplotypes, polymorphic sites, transitions, transversions, and haplotype $(h)$ and nucleotide $(\pi)$ diversities], besides a population comparisons by pairwise $F$-statistics, were calculated by using Arlequin version 3.1 software (Schneider et al., 2000), in order to reveal the level of genetic variation and population structure. To correct for multiple comparisons, the sequential Bonferroni correction was applied. Spatial analysis of molecular variance (SAMOVA) was performed using SAMOVA v.1.0 (Dupanloup et al., 2002), indicated the amount of genetic variation, as well as geographically homogeneous population clusters. Finally, the CONTRIB version 1.02 software (Petit et al., 1998) was used to evaluate the contribution of each population to total diversity, as measured by allelic richness (CTR).

\section{Results}

\section{Genetic variability, haplotype distribution and haplotype network relationships}

A total of 368 bp of unambiguous COI sequence alignments, with ten $(2.7 \%)$ variable nucleotide positions and six (1.6\%) parsimoniously informative sites, were obtained. Nine of the base substitutions were transitions, whereas only one was a transversion. All the variable sites occurred at the third codon position. Altogether, eleven unique putative haplotypes were identified from all the 238 individuals sampled. The mean base composition (\%) was 24.7A: 20.2G: 29.9T: 25.2C. In the eastern region (Perak River, Batang Padang - Sungkai river and Kinta river systems), haplotype 01 was predominant and unique, whereas haplotype 07 was common but not exclusive to the western Kerian river system. Most of the haplotypes were shared by multiple populations, with only three haplotypes being population specific. Nine of the 11 haplotypes (except 04 and 07) were unique to either the eastern or western regions. Haplotypes 01, 07 and 04 were the most common, contributing with $59.2 \%, 21 \%$ and $9.7 \%$, respectively, to total haplotype occurrence. 
The genetic variability parameters, viz., nucleotide and haplotype diversities, in populations, river systems and the total population, are presented in Table 2. Nucleotide and haplotype diversities ranged from 0.0007 to 0.0067 and 0.1000 to 0.7879 , respectively. As a whole, relatively low mean population nucleotide $(0.0048)$ and haplotype (0.5964) diversities were observed. Although much higher genetic variation was observed in upstream populations, this was only moderate downstream ones, reaching the lowest in upper-middle and mid-stream populations. In general, genetic diversity was slightly higher in upper-mid stream than in mid-stream populations. In the upstream populations, diversity was high ( $h: 0.7126$ to 0.7879 and $\pi: 0.0052$ to 0.0067 ), thereby contributing significantly to total genetic diversity (Figure 2), whereas in the remainder, this was low to moderate ( $h$ : 0.1000 to 0.3333 and $\pi$ : 0.0013 to 0.0030 ). Low genetic variability ( $h: 0.2541$ to 0.4914 and $\pi: 0.0025$ to 0.0035 ) was also observed when all the populations in the same river system were treated as a single entity.

\section{Population differentiation $\left(\mathrm{F}_{\mathrm{ST}}\right)$ and the spatial} analysis of molecular variation (SAMOVA)

Overlapping haplotype distribution, haplotype sharing and low nucleotide mutation among all the populations, were apparent from the data. Nevertheless, substantial genetic differentiation was observed among the western and eastern lineages $\left(\mathrm{F}_{\mathrm{ST}}\right.$ ranging from 0.4535 to 0.8526 and SAMOVA with $\mathrm{F}_{\text {Ст }}$ : 0.6210) (Tables 3 and 4). However, with the exception of the Grik, Tanjung Rambutan and Sungkai populations, no significant genetic differentiation among populations within river systems and regions themselves was detected (Table 3). In the Perak river, genetic differentiation between the upstream Grik population and the downstream population Kampung Gajah, was insignificant. Interestingly, no significant differentiation ( $\mathrm{F}_{\mathrm{ST}}: 0.0000$ to 0.0244 ) was observed when assessing pairwise comparison of the Grik, Sungkai and Tanjung Rambutan populations, although the three belonged to different river systems, i.e., they were genetically similar to each

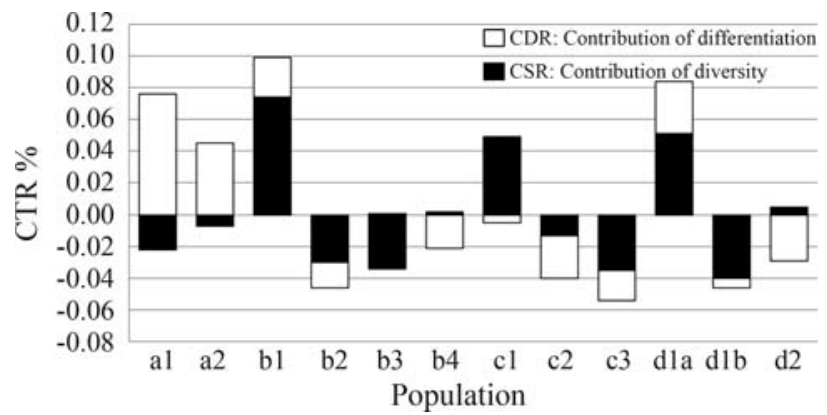

Figure 2 - The contribution of each Channa striata population to total diversity $(C T R)$, as described by allelic richness. White bars represent the contribution of differentiation $(C D R)$ and black the contribution of diversity (CSR). other but not to other members within their own river system and region. Furthermore, in the eastern region, where all the various populations, through occupying one and the same river system, were treated as a single group, low and insignificant mutual population differentiation $\left(\mathrm{F}_{\mathrm{ST}}\right.$ ranging from 0 to 0.0122 ) was recorded. Limited statistical analysis could be applied to the western region, consisting of only one river system (the Kerian river) comprising two populations. The Parit Buntar, Kubu Gajah, Grik and Sungkai populations were the main contributors to population differentiation among all those studied (Figure 2).

SAMOVA analysis indicated that $62.10 \%$ of the total variation existed between the two regions, $4.84 \%$ among populations within the region itself, and $33.06 \%$ within the populations, with significant support at all hierarchical levels. Furthermore, the SAMOVA tests also showed that a large proportion of the molecular variance was attributable to genetic differences among populations within the total ( $\left.\mathrm{F}_{\mathrm{ST}}: 0.6694\right)$ and to differences between the eastern and western regions $\left(\mathrm{F}_{\mathrm{CT}}\right.$ : 0.6210$)$. However, inspection of the data revealed that the significant (although low) differences among populations within regions $\left(\mathrm{F}_{\mathrm{SC}}: 0.1277\right)$ were contributed by the three genetically significantly different upstream populations, Tanjung Rambutan, Grik and Sungkai.

\section{Discussion}

\section{Genetic variation}

Despite their abundance and wide distribution, as well as several biologically advantageous attributes, genetic variation was relatively low (mean $h: 0.5964$, $\pi: 0.0048)$ in the $C$. striata populations investigated. The three upstream populations near the riverheads, upstream Grik, Tanjung Rambutan and Sungkai, revealed high genetic diversity, whereas in the three downstream populations this was moderate, and very low in the six uppermiddle and mid- stream ones. From this it can be inferred that upstream populations are colonizing centers or refugia. These refugia harbour high variability (with $h: 0.7126$ to 0.7879 and $\pi$ : 0.0052 to 0.0067 ), thereby implying a large initial effective population size. Pleistocene glaciation periods gave origin to substantial habitat re-organization, subsequently leading to the displacement of populations into glacial refugia, thereby giving rise to high intraspecific diversity, both through secondary contact between differentiated assortments, as also with the local gene pool, as appraised by Grant and Bowen (1998) and Petit et al. (2003) in marine fishes and European trees shrubs, respectively. Nevertheless, no refugium was detected, neither in the western region nor in the Batang Padang river in the eastern, probably due to limited sampling effort, although it is very likely such a parallel pattern does exist. Interestingly, all putative refugia were located in the upstream reaches, thereby indicating altitudinal shifts in refugee movements during the interglacial period. 


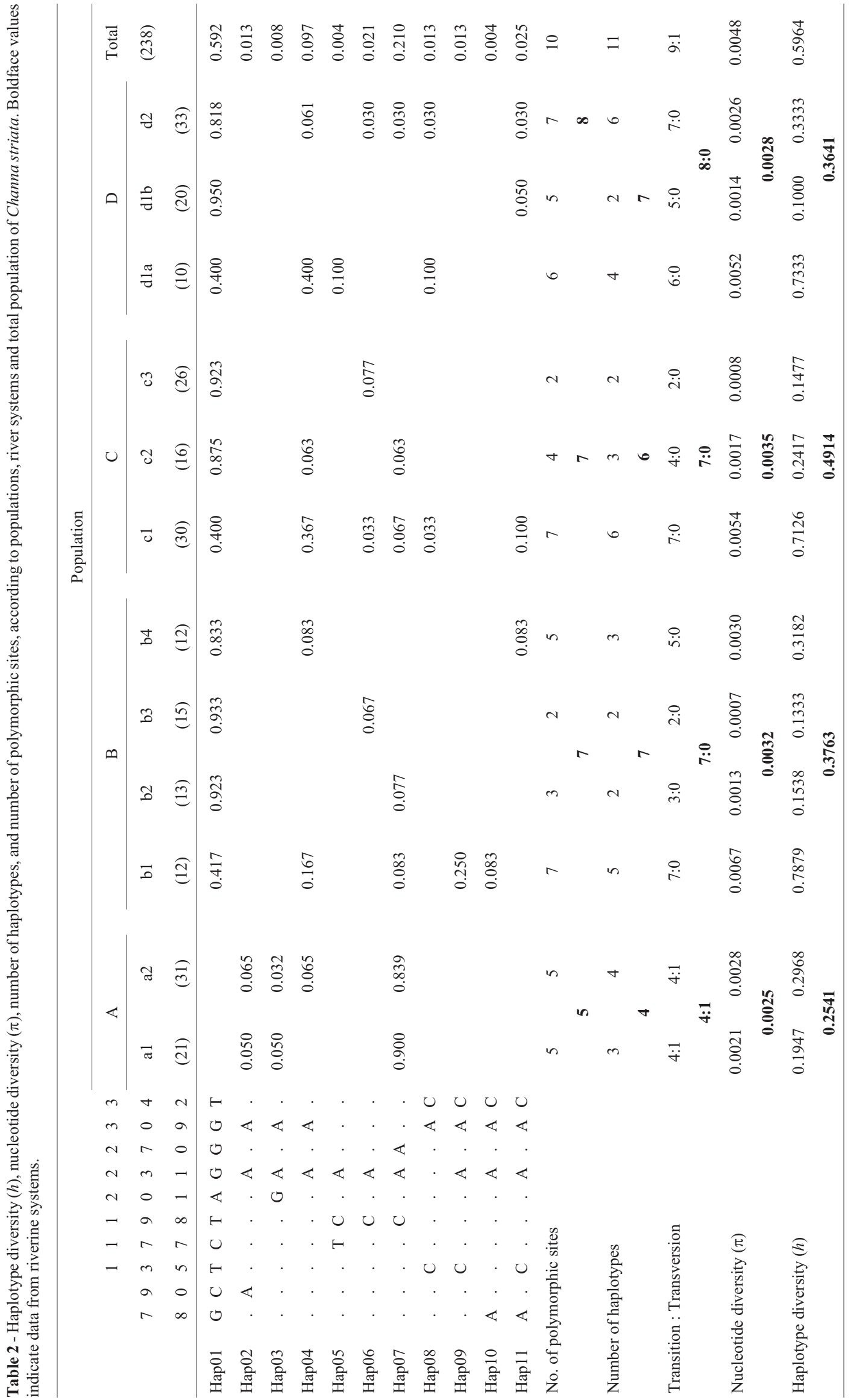


Table 3 - Pairwise $\mathrm{F}_{\mathrm{ST}}$ between populations and river systems (indicated in boldface) of C. striata, based on the COI gene. Significant $\mathrm{F}_{\mathrm{ST}}(\mathrm{p}<0.05$, $\mathrm{p}<0.01$ and $\mathrm{p}<0.001$ ) based on 10000 permutations of haplotype frequencies among samples, after Bonferroni correction, are indicated with *, $\dagger$ and $\ddagger$, respectively.

\begin{tabular}{|c|c|c|c|c|c|c|c|c|c|c|c|c|c|c|}
\hline & a1 & $\mathrm{A} 2$ & $\mathbf{A}$ & b1 & b2 & b3 & b4 & B & $\mathrm{c} 1$ & c2 & c3 & C & d1a & $\mathrm{d} 1 \mathrm{~b}$ \\
\hline \multicolumn{15}{|l|}{ a1 } \\
\hline a2 & 0.0000 & & & & & & & & & & & & & \\
\hline \multicolumn{15}{|l|}{$\mathbf{A}$} \\
\hline b1 & $0.5185 \$$ & $0.4764+$ & & & & & & & & & & & & \\
\hline b2 & $0.8086 \%$ & $0.7342 \ddagger$ & & $0.2348 \dagger$ & & & & & & & & & & \\
\hline b3 & $0.8320 \ddagger$ & $0.7616 \$$ & & $0.2704 \dagger$ & 0.0000 & & & & & & & & & \\
\hline b4 & $0.7565 \$$ & $0.6945 \ddagger$ & & 0.1344 & 0.0000 & 0.0000 & & & & & & & & \\
\hline B & & & 0.6728 & & & & & & & & & & & \\
\hline $\mathrm{c} 1$ & $0.4870 \%$ & $0.4535 \$$ & & 0.0244 & $0.2468 \dagger$ & $0.2677 \dagger$ & $0.1448 *$ & & & & & & & \\
\hline c2 & $0.7711+$ & 0.7075 \$ & & $0.1901^{*}$ & 0.0000 & 0.0000 & 0.0000 & & $0.2008 \dagger$ & & & & & \\
\hline c3 & $0.8315 t$ & $0.7724+$ & & $0.3211 \ddagger$ & 0.0000 & 0.0000 & 0.0088 & & $0.3035 \ddagger$ & 0.0000 & & & & \\
\hline C & & & $0.5976 \ddagger$ & & & & & 0.0122 & & & & & & \\
\hline d1a & $0.5992 \ddagger$ & $0.5440 \%$ & & 0.0073 & $0.3256 \dagger$ & $0.3563 \dagger$ & $0.1805^{*}$ & & 0.0000 & $0.2567 *$ & $0.4082 \ddagger$ & & & \\
\hline $\mathrm{d} 1 \mathrm{~b}$ & $0.8526 \%$ & $0.7839 \ddagger$ & & $0.3282 \ddagger$ & 0.0000 & 0.0000 & 0.0000 & & $0.3021 \ddagger$ & 0.0000 & 0.0000 & & $0.4199 \$$ & \\
\hline $\mathrm{d} 2$ & $0.7152 \ddagger$ & $0.6750 \$$ & & $0.1793 \dagger$ & 0.0000 & 0.0000 & 0.0000 & & $0.1907 \ddagger$ & 0.0000 & 0.0045 & & $0.2309 \dagger$ & 0.0089 \\
\hline D & & & 0.6813 & & & & & 0.0000 & & & & 0.0047 & & \\
\hline
\end{tabular}

Table 4 - Spatial analysis of molecular variance (SAMOVA) between populations of Channa striata in Perak State. Significant values at $\mathrm{p}<0.05$ and $\mathrm{p}<0.001$ are indicated with * and $\$$, respectively.

\begin{tabular}{lccccc}
\hline Source of variation & d.f. & Sum of squares & Variance components & Percentage of variation & $F$ statistics \\
\hline Among groups & 1 & 77.661 & $0.9394 \mathrm{Va}$ & 62.10 & $\mathrm{~F}_{\mathrm{CT}}: 0.6210 *$ \\
Among populations within groups & 10 & 18.863 & $0.0732 \mathrm{Vb}$ & 4.84 & $\mathrm{~F}_{\mathrm{SC}}: 0.1277 \ddagger$ \\
Within populations & 226 & 113.027 & $0.5001 \mathrm{Vc}$ & 33.06 & $\mathrm{~F}_{\mathrm{ST}}: 0.6694 \ddagger$ \\
Total & 237 & 209.550 & 1.5127 & & \\
\hline
\end{tabular}

The lower genetic variability recorded in the upper-middle, mid- and downstream populations may reflect their re-colonisation via successive founder events, each with a relatively low $\mathrm{Ne}$ value, and by either a single or only few organelle-lineage colonisation (Grant and Bowen, 1998; Wang et al., 2000), in a passive downstream dispersal-migration route. This downstream migration pattern had already been documented in a study by Halls et al. (1998) of C. striata in Bangladesh. Alternatively, the low variability observed in these three populations could also be the result of a historical bottleneck event that may have almost eradicated these populations. Notwithstanding, genetic variation in three downstream populations, viz., the Parit Buntar, Kampung Gajah and Teluk Intan, was higher than in the upper-middle and mid ones. Presumably their downstream location was more propitious for the overlapping of colonisation routes, with concomitant admixture of haplotypes or alleles from several separate refugia, or other connected river systems. This had already been observed in other studies of the same scenario (Nguyen et al., 2006).

\section{Phylogeographic relationships}

Based on $\mathrm{F}_{\mathrm{ST}}$ and SAMOVA analyses, three genetically different groups were identified: (1) the western region, (2) an upstream population in the eastern region, and (3) a mid downstream population, also in the eastern region. These populations were, however, incompletely divergent, evident by overlapping haplotype distribution, haplotype sharing and low nucleotide mutation. The lack of genetic divergence within geographical regions (except in refugia), incompatible with the low migratory behavior of C. striata (Halls et al., 1998; Amilhat and Lorenzon, 2005), implied factors other than free gene flow, possible alternatives being either recent population expansion with insufficient time for coalescence (cf. Wang et al., 2000), or interconnection of the areas studied. Mid and lower stream topology may not have been a sufficient hindrance against gene flow, when compared to the situation upstream. Furthermore, this region is also liable to high flooding (Mohsin and Ambak, 1983; Liu and Chan, 2003), thereby facilitating lateral dispersal to flood plains, watersheds or between 
adjacent populations (Hurwood and Hughes, 1998; Wang et al., 2000).

Two topographically isolated stocks of C. striata were revealed. Geographical separation by the Bintang mountain range, and changes in sea-water level during the Pleistocene, constitute two significant elements which have probably influenced the genetic distribution pattern of $C$. striata between the western and eastern regions of this highland. This mountain range, composed of several prominent peaks up to $1800 \mathrm{~m}$ high, only permitted genetic exchange between the systems at the ancient confluence, now submerged into the bed of the Strait of Malacca. Periodic changes in sea level witnessed the disappearance of this historical connection, with subsequently isolated populations forming distinct evolutionary units. Overlapping haplotype distribution and sharing, as well as low nucleotide mutation, provide ample evidence of this connection. It is apparent that, following construction of the Chenderoh dam across the Perak river in the 1930's, insufficient time has passed for any marked differentiation to have occurred among the isolated populations (cf. Hurwood and Hughes, 1998; Sun et al., 2004). Nevertheless, this event could potentially lead to substantial genetic restructuring over time, especially with the complete isolation of the genetically richer upstream sites from downstream populations. Similarly, the Keledang Mountain Range has not contributed to any obvious genetic divergence between the Perak and Kinta Rivers.

In theory, population segregation will normally contribute to genetic differentiation among isolated populations (cf. Hurwood and Hughes, 1998; Wang et al., 2000). Thus, it was unusual to discover that the three presumptive refugia in different rivers were genetically very closely related. Due to the small-sized study area, one possible factor could be the absence of the suitable ecological heterogeneity for stimulating overall local adaptation. Furthermore, all the populations were either of a common origin, or originated from a single colonization unit, seeing that during the glaciation period, each refugium maintained or accumulated all (or almost all) the haplotypes either from the original population or from other sites. Thirdly, the cytochrome oxidase subunit 1 (COI) was incapable of detecting population variability in this species, probably due to its relatively low mutation rate (Hebert et al., 2003; Hellberg, 2006), but also to the short time-span since population contraction into refugia during the last Pleistocene, insufficient for observable genetic differentiation to have occurred.

Overall, physical barriers to gene flow are thought to have played an important role in establishing evolutionary units between the two separate regions, whereas within each region, it appears that historical processes leading to environment disturbance and subsequent habitat re-organisation, have played a more predominant role in structuring the genetic dispersal of the species.

\section{Conservation and management implications}

The conservation of species is a source of great concern, especially regarding those endangered and/or of high economic value. This study provided useful and critical genetic information for planning management, conservation and ranching guidelines for $C$. striata in the biodiversityrich Perak State. Nevertheless, based on limited genetic information, all inferences should be reconfirmed using faster evolving markers, such as microsatellites. Based on $\mathrm{F}_{\mathrm{ST}}$ and SAMOVA analyses, two genetically identified stocks, the eastern and the western, were detected, both requiring separate monitoring and management (Moritz, 1994). Translocation between the two is not recommended, to thus avoid genetic disruption (Jørstad and Farestveit, 1999), adverse competition (Minckley, 1995), or the introduction of diseases (Mahidol et al., 2007). Furthermore, in the case of restoration involving local stock enhancement, special precautions must be taken, as this species reportedly exerts a negative ecological impact on aquatic communities, mainly due to its carnivorous behaviour (Cagauan, 2007; Froese and Pauly, 2008). With respect to the eastern region, if the upstream population as a source of gene pool for downstream populations could be verified, stock transfer from the former could be a beneficial option. Otherwise, they should be managed separately. Furthermore, as the more elevated upstream areas harbor a large proportion of the total genetic variation in this region, maximum priority for conservation should be given to this area. A strict regulation of harvest and fishery management should be implemented to protect genetically depauperate downstream populations. Habitat protection from agricultural and industrial activities, including the development of surrounding areas, as well as the construction of river-dams which prevent population connectivity, must be carefully regulated, seeing that the latter brings about habitat fragmentation, thereby potentially causing further losses in genetic diversity or an increase in inbreeding depression. As an alternative, the introduction and improvement of $C$. striata aquaculture is a fine option for ensuring the maintenance of this species. Nevertheless, hatchery facilities and operation, as well as brood-stock selection, must be systematically controlled, so as to prevent fugitive genetic contamination into the wild and other adverse genetic risks (Mahidol et al., 2007). Based on its high genetic variability and positive contribution towards genetic variation in this region, Grik, Sungkai and Tanjung Rambutan are the most appropriate candidate population of wild species to receive priority as a baseline stock for selective breeding.

\section{Acknowledgments}

This work is a collaborative project between the Aquaculture Research Group, School of Biological Sciences, Universiti Sains Malaysia and the Perak state government, funded by the Ministry of Science, Technology \& 
Innovation (MOSTI) (304/PBIOLOGI/6521033/U128). We would like to thank Dr. Thuy T.T. Nguyen from the Network of Aquaculture Centres in Asia-Pacific (NACA), Bangkok, Thailand and Dr. Geoffrey K. Chambers from Victoria University, Wellington, New Zealand for their valuable comments and analyses of our manuscript. We are also grateful to our colleagues for their technical assistance.

\section{References}

Ali AB (1999) Aspects of the reproductive biology of female snakehead (Channa striata Bloch) obtained from irrigated rice agroecosystem, Malaysia. Hydrobiologia 411:71-77.

Ambak MA, Bolong AA, Ismail P and Tam BM (2006) Genetic variation of snakehead fish (Channa striata) populations using random amplified polymorphic DNA. Biotechniques 5:104-110.

Amilhat E and Lorenzen K (2005) Habitat use, migration pattern and population dynamics of chevron snakehead Channa striata in a rainfed rice farming landscape. J Fish Biol 67 (Supplement B):23-34.

Arul V (2008) Effects of delayed feeding on growth and survival of Channa striatus (Bloch) larvae. Aquac Res 22:423-434.

Baie SH and Sheikh KA (2000) The wound healing properties of Channa striatus - cetrimide cream - tensile strength measurement. J Ethnopharmacol 71:93-100.

Beaumont AR and Hoare K (2003) Biotechnology and Genetics in Fisheries and Aquaculture. Blackwell Science, Oxford, $158 \mathrm{pp}$.

Cagauan AG (2007) Review paper: Exotic aquatic species introduction in the Philippines for aquaculture - A threat to biodiversity or a boon to the economy? J Environ Sci Manag 10:48-62.

Chandra S and Banerjee TK (2004) Histopathological analysis of the respiratory organs of Channa striata subjected to air exposure. Veterinarski Archiv 74:37-52.

Dupanloup I, Schneider S and Excoffier L (2002) A simulated annealing approach to define the genetic structure of populations. Mol Ecol 11:2571-2581.

Grant WAS and Bowen BW (1998) Shallow population histories in deep evolutionary lineages of marine fishes: Insights from sardines and anchovies and lessons for conservation. $\mathrm{J}$ Hered 89:415-426.

Halls AS, Hoggarth DD and Debnath K (1998) Impact of flood control schemes on river fish migrations and species assemblages in Bangladesh. J Fish Biol 53 (Supplement A):358-380.

Haniffa MA, Merlin T and Mohamed JS (2000) Induced spawning of the striped murrel Channa striatus using pituitary extracts, human chorionic gonadotropin, luteinizing hormone releasing hormone analogue, and ovaprim Acta Icht Piscat 30:53-60.

Hara M, Sekino M and Na-Nakorn U (1998) Genetic differentiation of natural populations of the snake-head fish, Channa striatus in Thailand. Fish Sci 64:882-885.

Hebert PDN, Cywinska A, Ball SL and de Waard JR (2003) Biological identifications through DNA barcodes. Proc R Soc Lond B Biol Sci 270:313-321.

Hellberg ME (2006) No variation and low synonymous substitution rates in coral mtDNA despite high nuclear variation. BMC Evol Biol 6:24.
Hossain MK, Latifa GA and Rahman MM (2008) Observations on induced breeding of snakehead murrel, Channa striatus (Bloch, 1793). Int J Sustain Crop Prod 3:65-68.

Hurwood DA and Hughes JM (1998) Phylogeography of the freshwater fish, Mogurnda adspersa, in streams of northeastern Queensland, Australia: Evidence for altered drainage patterns. Mol Ecol 7:1507-1517.

Jørstad KE and Farestveit E (1999) Population genetic structure of lobster Homarus gammarus in Norway, and implications for enhancement and sea-ranching operation. Aquaculture 173:447-457.

Lee PG and Ng PKL (1994) The systematics and ecology of snakeheads (Pisces, Channidae) in Peninsular Malaysia and Singapore. Hydrobiologia 285:59-74.

Liu P and Chan NW (2003) The Malaysian flood hazard management program. Int J Emerg Manag 1:205-214.

Mahidol C, Na-Nakorn U, Sukmanomon S, Taniguchi N and Nguyen TTT (2007) Mitochondrial DNA diversity of the Asian moon scallop, Amusium pleuronectes (Pectinidae), in Thailand. Mar Biotechnol 9:352-359.

Mat Jais AM, Abdul Rahim MH, Alias R and Muhammad N (2009) Genetic marker for haruan Channa striatus. In: Procedings of the $8^{\text {th }}$ Malaysia Congress on Genetics 2009, Genting Highland, Malaysia, pp 29.

Mat Jais AM, McCulloh R and Croft K (1994) Fatty acid and amino acid composition in haruan as a potential role in wound healing. Gen Pharmacol 25:947-950.

Michelle NYT, Shanti G and Loqman MY (2004) Effect of orally administered Channa striatus extract against experimentally-induced osteoarthritis in rabbits. Int J Appl Res Vet Med 2:171-175.

Minckley WL (1995) Translocation as a tool for conserving imperiled fishes: Experiences in Western United States. Biol Conserv 72:297-309.

Mohsin AKM and Ambak MA (1983) Freshwater Fishes of Peninsular Malaysia. Penerbitan Universiti Pertanian Malaysia, Kuala Lumpur, 284 pp.

Moritz C (1994) Defining "Evolutionarily Significant Units" for conservation. Trends Ecol Evol 9:373-375.

Nagarajan M, Haniffa MA, Gopalakrishnan A, Basheer VS and Muneer A (2006) Genetic variability of Channa punctatus populations using randomly amplified polymorphic DNA. Aquac Res 37:1151-1155.

Nguyen TTT, Hurwood D, Mather P, Na-Nakorn U, Kamonrat W and Bartley D (2006) Manual on applications of molecular tools in aquaculture and inland fisheries management, Part 2: Laboratory protocols and data analysis. NACA monograph number 2, $134 \mathrm{pp}$.

Petit RJ, Aguinagalde I, de Beaulieu JL, Bittkau C, Brewer S, Cheddadi R, Ennos R, Fineschi S, Grivet D, Lascoux M et al. (2003) Glacial refugia: Hotspots but not melting pots of genetic diversity. Science 300:1563-1565.

Petit RJ, El Mousadik A and Pons O (1998) Identifying populations for conservation on the basis of genetic markers. Conserv Biol 12:844-855.

Posada D (2006) Collapse: Describing Haplotypes from Sequence Alignment. Computational Evolutionary Biology Lab, University of Vigo.

Roshada H (1994) The effect of mixed feeding schedules of varying dietary protein content on the growth performance of Channa striata fry. Asian Fish Sci 7:149-155. 
Samantaray K and Mohanty SS (1997) Interactions of dietary levels of protein and energy on fingerling snakehead, Channa striata. Aquaculture 156:241-249.

Schneider S, Roessli D and Excoffier L (2000) Arlequin v. 2000: A software for population genetic data analysis. Genetics and Biometry Laboratory, University of Geneva.

Sun Y, Liu S, Zhao G, He S, Wu Q, Taniguchi N and Yu Q (2004) Genetic structure of Chinese sucker population Myxocyprinus asiaticus in the Yangtze River based on mitochondrial DNA marker. Fish Sci 70:412-420.

Tamura K, Dudley J, Nei M and Kumar S (2007) MEGA4: Molecular Evolutionary Genetics Analysis (MEGA) v. 4.0. Mol Biol Evol 24:1596-1599.

Teletchea F, Laudet V and Hänni C (2006) Phylogeny of the Gadidae (sensu Svetovidov, 1948) based on their morphology and two mitochondrial genes. Mol Phylogenet Evol 38:189-199.

Valles-Jimenez R, Cruz P and Perez-Enriquez R (2004) Population genetic structure of Pacific white shrimp (Litopenaeus vannamei) from Mexico to Panama: Microsatellite DNA variation. Mar Biotechnol 6:475-484.

Voris HK (2000) Maps of Pleistocene sea levels in Southeast Asia: Shorelines, river systems and time durations. J Biogeogr 27:1153-1167.
Wang JP, Hsu KC and Chiang TY (2000) Mitochondrial DNA phylogeography of Acrossocheilus paradoxus (Cyprinidae) in Taiwan. Mol Ecol 9:1483-1494.

Wee KL (1982) The biology and culture of snakeheads. In: Muir JF and Roberts RJ (eds) Recent Advances in Aquaculture. Westview Press, Boulder, pp 180-211.

Zakaria ZA, Mat Jais AM, Goh YM, Sulaiman MR and Somchit MN (2007) Amino acid and fatty acid composition of an aqueous extract of Channa striatus (haruan) that exhibits antinociceptive activity. Clin Exp Pharmacol Physiol 34:198-204.

Zuraini A, Somchit MN, Solihah MH, Goh YM, Arifah AK, Zakaria MS, Somchit N, Rajion MA, Zakaria ZA and Mat Jais AM (2006) Fatty acid and amino acid composition of three local Malaysian Channa spp. fish. Food Chem 97:674-678.

\section{Internet Resources}

Froese R and Pauly D (eds) (2008) FishBase. World Wide Web electronic publication. www.fishbase.org (11/2008).

Associate Editor: Fábio de Melo Sene

License information: This is an open-access article distributed under the terms of the Creative Commons Attribution License, which permits unrestricted use, distribution, and reproduction in any medium, provided the original work is properly cited. 